Journal Universitas Muhammadiyah Gresik Engineering, Social Science, and Health International Conference (UMGESHIC)

UMGCINMATIC : $1^{\text {st }}$ Rethinking Education during Covid-19 Era: Challange and Innovation

\title{
THE EFFECT OF PROACTIVE PERSONALITY AND CO-WORKERS' SOCIAL SUPPORT ON CAREER ADAPTABILITY
}

\author{
Author \\ Reza Ayu Ningrum ${ }^{1}$, Idha Rahayuningsih ${ }^{2}$, Chandrania Fastari ${ }^{3}$ \\ 1,2,3Psychology Faculty, Universitas Muhammadiyah Gresik \\ Email: rezaningrum_170701@umg.ac.id ${ }^{1}$, idha.rahayuningsih@umg.ac.id ${ }^{2}$, \\ chandraniafastari.psi@gmail.com ${ }^{3}$
}

\begin{abstract}
.
Vocational high school graduates are equipped with skills and expertise. However, currently, there is a rapid change in the work environment that requires new career skills. It is managing them effectively to survive. So, graduates can easily adapt to the work environment. Career adaptability is needed. The purpose of this study was to determine: (1) the effect of proactive personality and co-workers social support on career adaptability, (2) the effect of proactive personality on career adaptability, and (3) the effect of co-workers' social support on career adaptability. This study used a correlational quantitative approach with 25 students as a population. The researcher used a total sampling technique. The method of collecting data from the third variable (career adaptability, proactive personality, and co-workers' social support) used a questionnaire compiled in the form of a Likert scale. The data analysis of the three variables used multiple linear regression techniques. Based on the results obtained, there is no effect of proactive personality and co-workers' social support on career adaptability. There is an effect of proactive personality on career adaptability. There is no effect of co-workers' social support on career adaptability. The benefit of this research is to enrich the data information on the psychology development regarding the variables of career adaptability, proactive personality, and co-workers' social support. The limitation of this study is the lack of subjects. So, future researchers are expected to be able to enhance the research subjects and pay more attention to demographic factors.
\end{abstract}

Keywords: Proactive Personality, Co-Workers' Social Support, and Career Adaptability 


\section{INTRODUCTION}

Government Regulation (PP) Number 10 the Year 2017 stated that the enforcement of vocational high school has a purpose to prepare the students with skills and expertise in a specific field in order to be ready to enter the work environment as a productive worker and able to develop theirselves to create jobs through entrepreneurship (Sumantri et.al., 2019:153). The vocational high school graduates are equipped with specific expertise becomes their attraction for the requiters [1].

The Central Bureau of Statistics (BPS) claimed that vocational high school graduates have around 6,88 million people's unemployment percentage in Indonesia in February 2020. Other than that, the requirements of the job keep changing. There are many reasons which react to the jobs' requirements such as rapid technological development, new kinds of jobs accompanied with the development of science and technology, various characters of production, service, construction, and work pattern which also keep changing, a variety of multivariate skill needs, to the response to environmental impacts and climate change.

It is natural that the size of the business and the industrial field look at the worker's qualifications of vocational high school graduates by paying attention to the competence, proficiency, and productivity at work. Since, this will be closely related to how good the knowledge, skills, skills, abilities, attitudes, and work culture of the workers are (Sutjipto, 2019: 104). Rapid changes in the work environment, work structure, and the introduction of new technologies that always have progress will lead to the need for new career skills and manage them effectively [2].

[3] define a career as a process that a person must go through to plan something and go through a fairly long selection. Each individual can use proper planning. However, someone's journey can often change one's career path. In addition, research conducted by [4] found that there was a phenomenon that occurred at senior high school X Bekasi. There were grade 12 students who did not yet have the ability to make choices in advanced study programs and make career plans. They were easily influenced by trends, parents' choices, and peers. Their research result shows that students' career decision-making is still influenced by the surrounding environment. Furthermore, there are still many students who do not recognize themselves, do not understand their abilities and interests.

[5] stated that if the students of vocational high school grade twelve can face the career transition well so that those students need to do proper career preparation. Proper career preparation might help students to find a propejobsob. There is a construct in a psychological field that discusses the readiness of career and work field is career adaptability [6]. [7] acknowledged that career adaptability is a readiness to overcome tasks 
that can be predicted for preparing and participating in the work role and unexpected adjustments that are asked by changes in the jobs and work conditions. Someone who has career adaptability focuses on the future, has a sense of self-control to reach the future, has the curiosity to test one's abilities and search for social opportunities, and has the selfconfidence to realize their future. Otherwise, if someone has less career adaptability, they will be apathetic, unable to decide, unrealistic, and holding back to achieving their career.

Savickas revealed that someone who cares about the process of achieving a career will show a good attitude, confidence, and have good planning competence such as concern, control, curiosity, and confidence. In the concern, someone can plan their future rationally to get appropriate roles with their interest, ability, and socioeconomic living conditions. Furthermore, in the concept of control, someone forms career patterns and has the ability to make a career decision. Curiosity means someone has knowledge about the work field and career information which help the maturity of career competencies. In addition, confidence marks strengthen the self-confidence to pursue aspiration. During the career-building process, someone will show attitude, confidence, and competence that are used to reach success in adapting to new situations [8].This situation needs to emphasize the importance of flexibility and the ability to adapt for job seekers. It is also needed by those who work not in accordance with their educational background. Therefore, adapting and having readiness in entering the work field is important things for anyone [9]. Career adaptability is critical to improving to accelerate regulatory adjustment process, co-workers, and new work environment [10]. There are some factors of career adaptability such as social support, hardiness, proactive personality, self-esteem, and work values.

The results of interviews conducted with four alumni of vocational high school Muhammadiyah 3 Gresik 2018 who worked, some still showed a lack of preparation and planning regarding their careers. The subject does not have a definite goal of what kind of job and company to aim for. At the beginning of work, the subject felt confused and nervous, because the subject encountered new work tools, did not understand the job desk, the knowledge obtained from school was inadequate, and there were differences between the work field and the school field. Furthermore, there are several things that alumni do to make it easier for them to adapt, by actively asking questions about things they don't understand to seniors, co-workers, and to people who are experienced in the workplace for building communication. This indicates that they have a proactive personality.

Someone who has a proactive personality is someone who is relatively unconstrained by situational forces and who influences changes in his environment [11]. Proactive people seek opportunities, show initiative, take action and persist until they reach closure by bringing about change [11]. In addition, research conducted by [12] on final year college students on "Peran Kepribadian Proaktif terhadap Adaptabilitas Karir pada Mahasiswa Tingkat Akhir " found that the role of proactive personality on career adaptability in final 
year students was $39.3 \%$. Thus, one way that can be done to improve career adaptability is to develop a proactive personality in students. Besides, [13] conducted a study on "Pengaruh kepribadian proaktif terhadap kesuksesan karir melalui adaptabilitas Karir" for employees of PT Bank Tabungan Negara (Persero) Tbk Surabaya Branch Office. It was found that the coefficient estimate has a value of 0.675 . This coefficient has a positive number, which means that if proactive personality is higher, so career adaptability will also be higher, and vice versa.

The results of the interview also show that the factors that influence them to be comfortable in their work are due to the support from co-workers. Co-workers help them in overcoming the difficulties they face. This indicates that social support from co-workers is needed in career adaptability. Co-workers' social support is the support given by co-workers to other workers who are perceived in the form of comfort, attention, appreciation, and assistance. The aspects of social support based on Sarafino \& Smith (2011) are emotional support, instrumental support, informational support, and friendly support.

Research conducted by [14] about "Pengaruh Social Support Terhadap Career Adaptability Mahasiswa Tingkat Akhir Fakultas Psikologi Universitas Airlangga" found that the regression results of the two variables were 0.034 , with a significance level of 0.000 $<0.05$. These results showed that there is an effect of social support on career adaptability in final year students of the Faculty of Psychology, Airlangga University. Social support has a positive effect on career adaptability, which means that the higher level of social support a person gets, the higher level of career adaptability. Research conducted by [15] regarding "Pengaruh Internal Locus of Control dan Dukungan Sosial Terhadap Career Adaptability". The subjects in this study were Economic Education students of UNNES 2015 and 2014. It was found that social support had a positive effect on career adaptability by $3,88 \%$. It indicates that social support partially affects the career adaptability of UNNES Economic Education students.

The purpose of this study was to determine the effect of proactive personality and coworkers' social support on career adaptability of alumni vocational high school Muhammadiyah 3 Gresik.

\section{METHODS}

The research method used is a quantitative method with the type of correlational research. This study used a saturated sampling of alumni of vocational high school (SMK) Muhammadiyah 3 Gresik who work as many as 25 people. There were 5 people from the Light Vehicle Engineering (TKR) department, 14 people from the Electrical Power Installation Engineering department (TITL), and 6 people from the Computer and Network 
Engineering department (TKJ). The instrument for collecting the data was a questionnaire with a Likert scale. The career adaptability scale used the Career Adapt-Abilities Scale proposed by Savickas \& Profeli (2012) which consists of 24 items. The researcher also used the Proactive Personality Scale (PPS) developed by Bateman \& Crant (1993) which consists of 17 items. The co-worker's social support scale was compiled by researchers based on the aspects proposed by Sarafino \& Smith (2011) which amounted to 30 items. The data analysis technique used in this study is multiple linear regression analysis. The entire statistical analysis process used in this study uses the IBM Statistical Program for Social Science (SPSS) for windows version 25 computer program.

\section{DISCUSSION}

The following are the results of the research that has been carried out:

\begin{tabular}{ccc} 
& \multicolumn{2}{c}{ Table 1 F Test } \\
& F & Sig. \\
\hline gression & 2.178 & .137 \\
\hline \multicolumn{3}{l}{ Source: SPSS 25 for windows }
\end{tabular}

The $\mathrm{F}$ test obtained a significance value of $0.137>0.05$, which means that the level of proactive personality (X1) and co-workers' social support (X2) has no significant effect on the level of career adaptability (Y). Thus, the first hypothesis is rejected.

Table 2 t-Test

\begin{tabular}{lccc} 
& \multicolumn{2}{c}{ Unstandardized Coefficients } & \multirow{2}{*}{ Sig. } \\
\cline { 2 - 3 } & $\mathrm{B}$ & Std. Error & \\
\hline onstant) & 54.299 & 21.793 & .021 \\
\hline Jactive Personality & .435 & .210 & .050 \\
\hline I-Workers' Social Support & .070 & .117 & .558 \\
\hline & \multicolumn{2}{l}{ Source: SPSS 25 for windows } &
\end{tabular}

The value of t-statistics aims to test the significance construct, the value of t-statistics with a significance level of $\alpha=5 \%$, is considered significant. The path coefficient shows the correlation between constructs, indicating a positive or negative direction. Based on table 2 can be seen:

a. The proactive personality shows the regression coefficient is positive $(0.435)$ and sig. $=$ $0.050=0.05$. It can be concluded that the second hypothesis is accepted. This means that there is a significant positive effect of proactive personality (X1) on career adaptability (Y) in alumni of vocational high school (SMK) Muhammadiyah 3 Gresik.

b. On the social support of co-workers, the regression coefficient is positive (0.70) and sig. $=0.558>0.05$. It can be concluded that the third hypothesis is rejected. This means that there is no significant positive effect of co-workers' social support (X2) on career adaptability (Y) in alumni of vocational high school (SMK) Muhammadiyah 3 Gresik.

Tabel 3 Coefficient of Determination 


\begin{tabular}{cc}
$\mathbf{R}$ & R Square \\
\hline .407 & .165 \\
\hline Source: SPSS 25 for windows
\end{tabular}

The coefficient of determination is used to determine the percentage of the independent variable which is given simultaneously to the dependent variable. Based on SPSS calculations, it is known that $\mathrm{R}$ Square is 0.165 , which means that the proactive personality variable and the co-worker's social support variable contribute $16.5 \%$ to the career adaptability variable. While the remaining $83.5 \%$ is influenced by other variables not examined.

Based on the results of the analysis of the $\mathrm{f}$ test and t-test, the results of the $\mathrm{F}$ value of 2.178 were obtained. Based on table 2 , it is found that the calculated $F$ value $=2.178$ and the significance value is $0.137>0.05$. The significance value is greater than 0.05 . So, it can be concluded that the regression line equation is not valid for predicting proactive personality and social support of co-workers.

Multiple linear regression equations can be formulated as follows:

$\mathrm{Y}=\mathrm{a}+\mathrm{b} \cdot \mathrm{X}_{1}+\mathrm{b} \cdot \mathrm{X}_{2}$

$\mathrm{Y}^{\prime}$ : The predicted value of a dependent variable (Economic profitability)

a : Constant, i.e. value $\mathrm{Y}^{\prime}$ if $\mathrm{X}=0$

b: Regression coefficient, namely the value of the increase or decrease in the $Y^{\top}$ variable based on the $X$. variable

$\mathrm{X}$ : Independent Variable (proactive personality and social support of co-workers)

The result of the equation is, $\mathrm{Y}=54.299+0,435 \mathrm{X}_{1}+0,070 \mathrm{X}_{2}$

\section{Table 4 F Test}

\begin{tabular}{ccc} 
& F & Sig. \\
\hline Regression & 4.117 & .050 \\
\hline & Source: SPSS 25 for windows
\end{tabular}

The F test obtained a significance value of 0.050 , which means that the proactive personality level variable (X1) has a significant effect on the level of career adaptability.

Table 5 t-Test

\begin{tabular}{lccc} 
& \multicolumn{2}{c}{ Unstandardized Coefficients } & \multirow{2}{*}{ Sig. } \\
\cline { 2 - 3 } & $\mathrm{B}$ & Std. Error & \\
\hline onstant) & 62.821 & 16.204 & .001 \\
\hline active Personality & .387 & .191 & .050
\end{tabular}

Source: SPSS 25 for windows

The proactive personality shows the regression coefficient is positive $(0.387)$ and sig. $=$ $0.050=0.05$, it can be concluded that the second hypothesis is accepted. It means that there is a significant positive effect of proactive personality (X1) on career adaptability (Y) in alumni of vocational high school (SMK) Muhammadiyah 3 Gresik.

Table 6 Coefficient of Determination

\begin{tabular}{cc}
$\mathbf{R}$ & R Square \\
\hline .390 & .152 \\
\hline Source: SPSS 25 for windows
\end{tabular}


The coefficient of determination is used to determine the percentage of the independent variable that is given simultaneously to the dependent variable. Based on SPSS calculations, it is known that $\mathrm{R}$ Square is 0.152 , which means that the proactive personality variable contributes $15.2 \%$ to the career adaptability variable. While the remaining $84.8 \%$ is influenced by other variables not examined.

Based on the results of the analysis of the $\mathrm{f}$ test and t-test, the results of the $\mathrm{F}$ value of 4.117 were obtained. Based on table 4.17, the calculated $\mathrm{F}$ value $=4.117$ and a significance value of 0.050 , so it can be concluded that the regression line equation is valid for predicting proactive personality. Multiple linear regression equations can be formulated as follows:

$\mathrm{Y}=\mathrm{a}+\mathrm{b} \cdot \mathrm{X}_{1}$

$\mathrm{Y}=62,821+0,387 \mathrm{X}_{1}$

The accepted hypothesis is the second hypothesis. Based on the results of the analysis of the $f$ test and t-test, the results of the $F$ value of 4.117 were obtained. Based on table 4.17, the calculated $F$ value $=4.117$ and a significance value of 0.050 . So, it can be concluded that the regression line equation is valid for predicting proactive personality.

The results of research that support the influence of proactive personality on career adaptability are research conducted by [12] that there is a role of proactive personality on career adaptability in final year students of $39.3 \%$ with a significance value of 0.000 (p $<0.05$ ). Participants in this study amounted to 270 final year students, each region in Jabodetabek was represented by 30 subjects. This study used the Career Adapt-Abilities Scale (CAAS) (24 items, $\alpha=0.946$ ) and Proactive Personality Scale (PPS) (17 items, $\alpha$ $=0.837$ ) which were translated into Indonesian.

This research is also in line with the results of research conducted by [1] which states that proactive personality has a significant positive effect on career adaptability by $45.5 \%$. The participants in this study were permanent/organic employees who worked at PT. Bank Tabungan Negara (Persero) Tbk Surabaya Branch Office with a sample of 41 permanent/organic employees. This study used the Career Adapt-Abilities Scale (CAAS) (24 items, $\alpha=0.909$ ) and Proactive Personality Scale (PPS) (17 items, $\alpha=0.933$ ) which were translated into Indonesian.

[7] emphasizes the individual's failure and success in building a career by emphasizing the ability to adapt and one's style when in certain situations and conditions. For example, the actions that appear in someone who is hesitant or following a friend for taking further studies or work will be different from the actions shown by someone who is determined about his decision to take a particular education or job.

The coefficient of determination in this study $\left(\mathrm{rho}^{2}\right)$ of the value of rho $=0.390^{2}=0.152$. That is, rho ${ }^{2}=0.152$ (meaning 15.2\%) informs that the contribution of the proactive personality variable to career adaptability in the alumni of vocational high school (SMK) Muhammadiyah 3 Gresik is $15.2 \%$. While the remaining $84.8 \%$ is influenced by other 
variables not examined. This result is different from the research conducted [1] which shows that the effect of proactive personality on career adaptability in final year college students shows a very significant effect with a correlation of $39.3 \%$. While research conducted by [2] reveal that the effect of social support on career adaptability in final year college students of the Faculty of Psychology, Airlangga University shows a very significant influence with a correlation of $2.2 \%$.

Other variables that have not been studied by $83.5 \%$ may be influenced by other factors that have not been used by researchers. According to research conducted by [1], one of the factors that influence career adaptability is self-esteem. This opinion is supported by research conducted by [3] that self-esteem with career adaptability in employees in one of the Islamic banking institutions in Banda Aceh has an effective contribution of 50.1\%.

\section{CONCLUSION}

The results of this study are that there is no significant influence of career adaptability variables and co-workers' social support on career adaptability of alumni of vocational high school (SMK) Muhammadiyah 3 Gresik. There is a significant effect of proactive personality on career adaptability of alumni of vocational high school Muhammadiyah 3 Gresik. In addition, there is no effect of co-workers' social support on career adaptability of alumni of vocational high school Muhammadiyah 3 Gresik. So, the first and third hypotheses are rejected, while the second hypothesis is accepted. Based on the research results, it is hoped that alumni will continue to develop their careers responsibly and carefully in making decisions about their careers. Career adaptability is closely related to the formation of vocational identity, where graduates can adapt and have various additional skills that make them more dynamic in choosing a field of work. For further researchers, it is to choose other subjects and consider demographic factors.

\section{REFERENCES}

Alissa, S., \& Akmal, S. Z. (2019). Career Decision Making Self-Efficacy Mediator Antara Dukungan Kontekstual dan Adaptabilitas Karier. Jurnal Psikologi Pendidikan \& Konseling: Jurnal Kajian Psikologi Pendidikan dan Bimbingan Konseling, 5 (1), 1-8. Aprilliofany, A. (2020). Analisis Penyebab Penganguran Lulusan Sekolah Kejuruan di Jawa Barat dan Garut. Jurnal Litbang Sukowati, 3 (2), 57-68.

Ariyati, A. D. (2019). Pengaruh Trait Hope Terhadap Career Adaptability pada Mahasiswa Jurusan Psikologi Unnes. Skripsi Psikologi, 1-101.

Bateman, T. S., \& Crant, J. M. (1993). The Proactive Component of Organizational 
Behavior: A Measure and Correlates. Journal of Organizational Behavior, 14, 103-118. Ebenehi, A. S., Rashid, A. M., \& Bakar, A. R. (2016). Predictors of Career Adaptability Skill among Higher Education Students in Nigeria. International Journal of Research in Vocational Education and Training, 3 (3), 212-229.

Fadli, R. P., Mudjiran, Ifdil, I., \& Amalianita, B. (2019). Peluang dan Tantangan Bimbingan Karir di Sekolah Menengah Kejuruan pada Era Revolusi Industri 4.0. Jurnal EDUCATIO: Jurnal Pendidikan Indonesia, 5 (2), 102-108.

Fatmawiyati, J. (2019). Gambaran Adaptabilitas Karir Siswa Sekolah Menengah Kejuruan. Jurnal Ilmu Pengetahuan, 04 (02), 481-494.

Giffari, N., \& Suhariadi, F. (2017). Pengaruh Social Support terhadap Career Adaptability pada Mahasiswa Tingkat Akhir Fakultas Psikologi Universitas Airlangga. Jurnal Psikologi Industri dan Organisasi, 6, 64-77.

Haris, F., \& Suryani, A. I. (2021). Pengaruh Self-Esteem terhadap Adaptabilitas Karir yang Dimediasi oleh Perceived Social Support pada Karyawan di salah satu Perbankan Syariah Kota Banda Aceh. Jurnal Ilmiah Mahasiswa Ekonomi Manajemen, 6 (2), 277294.

Hartomo, Giri. (2020). 6,88 Juta Orang Nganggur Paling Banyak Lulusan SMK, (Online), (https://economy.okezone.com/read/2020/05/05/320/2209470/6-88-juta-orang-nganggurpaling-banyak-lulusan-smk), diakses 26 Oktober 2020

Mahardika, M. D., \& Kistyanto, A. (2020). Pengaruh Kepribadian Proaktif terhadap Kesuksesan Karir melalui Adaptabilitas Karir. Forum Ekonomi, 22 (2), 185-195.

Nabilah, A., \& Indianti, W. (2019). Peran Efikasi Diri dalam Keputusan Karier terhadap Hubungan antara Future Work Self dengan Adaptabilitas Karier pada Mahasiswa Tingkat Akhir. Jurnal Psikologi Teori dan Terapan, 9 (2), 160-174.

Rosulin, R., \& Paramita, P. P. (2016). Hubungan antara Hardiness dengan Adaptabilitas Karir pada Siswa SMK Kelas XII. Jurnal Psikologi Pendidikan dan Perkembangan, 5 (1), 1-11.

Sarafino, E. P., \& Smith, T. W. (2011). Health Psychology. United States of America: John Wiley \& Sons, INC.

Savickas, M. L. (1997). Career Adaptability: An Integrative Construct for Life-Span, LifeSpace Theory. The Career Development Quarterly, 45, 247-259.

Savickas, M. L., Nota, L., Rossier, J., Dauwalder, J.-P., Duarte, M. E., Guichard, J., . . . Vianen, A. E. (2009). Life Designing: A Paradigm for Career Construction in the 21st Century. Journal of Vocational Behavior, 239-250.

Solichah, C., \& Setiaji, K. (2019). Pengaruh Internal Locus of Control dan Dukungan Sosial terhadap Career Adaptability. Economic Education Analysis Journal, 8 (2), 652-665.

Sumantri, D., Subijanto, Siswantari, \& Sudiyono. (2019). Pengembangan Sekolah Menengah Kejuruan Empat Tahun Bidang Keahlian Prioritas Program Nawacita. Jurnal 
Pendidikan dan Kebudayaan, 4 (2), 152-168.

Sutjipto. (2019). Perancangan Kurikulum Sekolah Menengah Kejuruan sebagai Pranata Budaya Kerja. Jurnal Pendidikan dan Kebudayaan, 4 (1), 102-126.

Ulfah, F., \& Akmal, S. Z. (2019). Peran Kepribadian Proaktif terhadap Adaptabilitas Karier pada Mahasiswa Tingkat Akhir. Intuisi, 11 (1), 45-54.

F. Ulfah and S. Z. Akmal, "Peran Kepribadian Proaktif terhadap Adaptabilitas Karier pada Mahasiswa Tingkat Akhir," Intuisi, vol. 11 (1), pp. 45-54, 2019.

N. Giffari and F. Suhariadi, "Pengaruh Social Support terhadap Career Adaptability pada Mahasiswa Tingkat Akhir Fakultas Psikologi Universitas Airlangga," Jurnal Psikologi Industri dan Organisasi, vol. 6, pp. 64-77, 2017.

F. Haris and A. I. Suryani, "Pengaruh Self-Esteem terhadap Adaptabilitas Karir yang Dimediasi oleh Perceived Social Support pada Karyawan di salah satu Perbankan Syariah Kota Banda Aceh," Jurnal Ilmiah Mahasiswa Ekonomi Manajemen, vol. 6 (2), pp. 277-294, 2021.

I. Yunita and A. Rahayu, "Internal Locus of Control dan Konsep Diri Hubungannya dengan Kematangan Karir Siswa SMA X Bekasi," Jurnal IKRA-ITH Humaniora, vol. 5 (1), pp. 168-176, 2021.

S. Alissa and S. Z. Akmal, "Career Decisio Makin Self-Efficacy Mediator Antara Dukungan Kontekstual dan Adaptabilitas Karier," Jurnal Psikologi \& Konseling, vol. vol. 5, pp. 1-8, 2019.

A. Aprilliofany, "Analisis Penyebab Pengangguran Lulusan Sekolah Kejuruan di Jawa Barat dan Garut," Jurnal Litbang Sukowati, vol. 3 (2), pp. 57-68, 2020.

A. D. Ariyati, "Pengaruh Trait Hope terhadap Career Adaptability Mahasiswa Jurusan Psikologi Unnes," Skripsi, 2016.

T. S. Bateman and J. M. Crant, "The Proactive Component of Organizational Behavior: A Measure and Correlates," Journal of Organizational Behavior, vol. 14, pp. 103-118, 1993.

A. S. Ebenehi, A. M. Rashid and A. R. Bakar, "Predictors of Career Adaptability Skill among Higher Education Students in Nigeria," International Journal of Research in Vocational Education and Training, vol. 3 (3), pp. 212-229, 2016.

R. P. Fadli, Mudjiran, I. Ifdil and B. Amalianita, "Peluang dan Tantangan Bimbingan Karir di Sekolah Menengah Kejuruan pada Era Revolusi Industri 4.0," Jurnal EDUCATIO: Jurnal Pendidikan Indonesia, vol. 5 (2), pp. 102-108, 2019.

J. Fatmawiyati, "Gambaran Adaptabilitas Karir Siswa Sekolah Menengah Kejuruan," Jurnal Ilmu Pengetahuan; Discovery, vol. 04(02), pp. 481-494, 2019. 
M. D. Mahardika and A. Kistyanto, "Pengaruh Kepribadian Proaktif terhadap Kesuksesan Karir melalui Adaptabilitas Karir," Forum Ekonomi, vol. 22 (2), pp. 185-195, 2020.

A. Nabilah and W. Indianti, "Peran Efikasi Diri dalam Keputusan Karier terhadap Hubungan antara Future Work Self dengan Adaptabilitas Karier pada Mahasiswa Tingkat Akhir," Jurnal Psikologi Teori dan Terapan, vol. vol. 9, pp. 160-174, 2019.

R. Rosulin and P. P. Paramita, "Hubungan antara Hardiness dengan Adaptabilitas Karir pada Siswa SMK Kelas XII," Jurnal Psikologi Pendidikan dan Perkembangan, vol. 5 (1), pp. 1-11, 2016.

E. P. Sarafino and T. W. Smith, Health Psychology, United States of America: John Wiley \& Sons, INC, 2011.

M. L. Savickas, "Career Adaptability: An Integrative Construct for Life-Span, Life-Space Theory," The Career Development Quarterly, vol. 45, pp. 247-259, 1997.

M. L. Savickas, L. Nota, J. Rossier, J. P. Dauwalder, M. E. Duarte, J. Guichard, S. Soresi, R. V. Esbroeck and A. E. v. Vianen, "Life Designing: A Paradigm for Career Construction in The 21st Century," Journal of Vocational Behavior, vol. 75, pp. 239-250, 2009.

C. Solichah and K. Setiaji, "Pengaruh Internal Locus of Control dan Dukungan Sosial terhadap Career Adaptability," Economic Education Analysis Journal, vol. 8 (2), pp. 652665, 2019.

D. Sumantri, Subijanto, Siswantari and Sudiyono, "Pengembangan Sekolah Menengah Kejuruan Empat Tahun Bidang Keahlian Prioritas Program Nawacita," Jurnal Pendidikan dan Kebudayaan, vol. 4 (2), pp. 152-168, 2019.

Sutjipto, "Perancangan Kurikulum Sekolah Menengah Kejuruan sebagai Pranata Budaya Kerja," Jurnal Pendidikan dan Kebudayaan, vol. 4 (1), pp. 102-126, 2019. 